\title{
歯周基本治療においてプラークコントロール期間が 歯周組織の改善に及ぽ影響
}

\author{
鈴木史彦山口貴司小野瀬規依田圭吾 \\ 河本和繁関野 愉岡本浩 \\ 奥羽大学歯学部歯科保存学第一講座 \\ (1999 年 7 月 10 日受理)
}

\section{Supragingival Plaque Control Period Effects in Periodontal Improvement after Initial Preparation}

\author{
Fumihiko Suzuki, Takashi Yamaguchi, Tadashi Onose, Keigo Yoda, \\ Kazushige Kawamoto, Satoshi Sekino and Hiroshi Okamoto \\ Department of Periodontics, Ohu University Faculty of Dentistry \\ Accepted for publication 10 July 1999
}

\begin{abstract}
The aim of the present investigation was to evaluate the effect of the supragingival plaque-control period combined with self-control and professional tooth cleaning in clinical improvement after initial preparation including scaling and root planing. Thirty-six patients with adult periodontitis were selected and were divided into 4 groups according to the supragingival plaque control period (1,2,3 and 6-months). Clinical parameters including plaque-control record, probing depth, probing attachment level and bleeding on probing after initial preparation were compared between the 4 groups. Plaque-control record improved before scaling and root planing and maintained a satisfactory level after initial preparation. At sites with 3-5 mm pockets before treatment, significant pocket reduction appeared after 3 and 6 months, and this reduction was greater than that at 1 and 2 months. The percentage of sites with probing attachment gain was significantly different in each group (45.1\% of 2-month group, and $62.1 \%$ of 3-month group). When bleeding on probing after initial preparation was compared, there was no significant values in each group. Thus, results suggest that setting a period of supragingival plaque-control for more than 3 months is important for improvement after initial preparation by scaling and root planing. J. Jpn. Soc. Periodontol., 41 : 331 338, 1999.
\end{abstract}

Key words : supragingival plaque control, scaling and root planing, initial preparation, clinical evaluation

要旨：本研究はセルフコントロールとプロフェッショナル・トゥース・クリーニングを組み合わせた歯肉縁上 プラークコントロールの期間が，スケーリング・ルートプレーニングを含む歯周基本治療後の改善に及ぼす影響 について臨床的に検討したものである。被験者は 36 名の成人型歯周炎患者とした。歯肉緑上プラークコント ロールの期間を $1 ， 2 ， 3$ および 6 カ月に振り分け，歯周基本治療後のプラークコントロールレコード，プロービ ングデプス，プロービングアタッチメントレベル，プロービング時の出血を比較した。各グループともにプラー クコントロールレコードはスケーリング・ルートプレーニング前に良好な状態に改善し，歯周基本治療後まで保 たれていた。初診時にプロービングデプスが 3〜 $5 \mathrm{~mm}$ であった部位は， 3 押よび 6 カ月のプシークコントロー ル期間であったグループが， 1 および 2 カ月のグループと比較して有意な減少を認めた。また，プロービングア

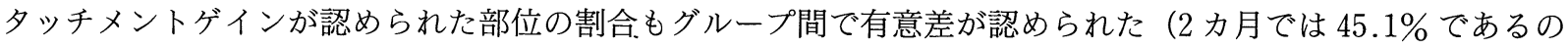

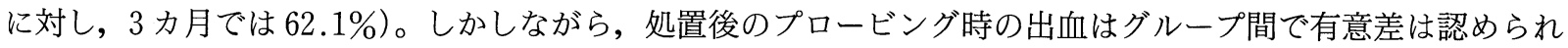
なかった。以上のことから，3 カ月以上の歯肉縁上プラークコントロール期間を設定することは，スケーリング ・ルートプレーニングを含む歯周基本治療後の改善に影響を及ぼすことが示唆された。 
索引用語：歯肉縁上プラークコントロール，スケーリング・ルートプレーニング, 歯周基本治療, 臨床評価

\section{緒言}

歯周治療の主な目的は歯肉縁上および歯肉縁下から 細菌性プラークを除去し，歯周組織の炎症を消退さ せ，獲得した健康を維持することにある。そのために は患者自身による適切なプラークコントロールが習慣 化されていることが必要不可欠であり，加えて専門的 なメインテナンスケアを行っていく必要がある1,2)。 歯肉縁上プラークコントロールが歯肉縁下に及ぼす影 響についての細菌学的な検索は，短期間（2 週から数 カ月）では影響が認められないとしているが3 6)，長 期間（2 年）では影響を及ぼすことが報告7)されてい る。しかしながら，治療目的として数年におよぶ歯肉 縁上プラークコントロールは非現実的である。また， 臨床的には患者自身による口腔清掃のみでは深い歯周 ポケットを有する部位において，歯周組織破壊を防ぐ ことは難しいことが報告8 11)されている。

プラークコントロールの期間とその後のスケーリン グ・ルートプレーニング (SRP) の関係について, Morrison ら ${ }^{12)}$ は口腔清掃指導とSRPを 4 回のアポ イントで終了し， 4 週後に再評価を行い，初診時に 4 〜 $6 \mathrm{~mm}$ のポケットにおいて平均 $0.96 \mathrm{~mm}$ の減少が みられたことを報告した。Hämmerle ら ${ }^{13)}$ は口腔清 掃指導と歯肉縁上スケーリングに $4 \sim 6$ 回のアポイン トをとってから SRP を施行し，再評価までの 3〜 5 カ月間は 4 週に 1 度のプロフェッショナル・トゥース ・クリーニングを行った。その結果, 初診時に $4 \sim 6$ $\mathrm{mm}$ のポケットは平均 $1.03 \mathrm{~mm}$ の減少がみられた。 一方 Cercek ら ${ }^{14)}$ は, 最初の 5 力月は患者自身による 歯肉縁上プラークコントロールとし, 続く 3 カ月は Perio-Aid ${ }^{\circledR を}$ 用いた患者自身による歯肉縁下プラーク コントロールとした後に歯肉縁上抢よび縁下スケーリ ングを施行し， 3 カ月ごとに再評価を行った。SRP 後 9 カ月時のポケットは初診時 (平均 $4.4 \mathrm{~mm}$ ) から 平均 $1.2 \mathrm{~mm}$ の減少がみられた。すなわち, プラー クコントロールの期間が長いほど, SRP 後のポケッ トの減少が大きいといえる。しかし，これらの研究は 歯肉緑上歯石を除去する時期，プロフェッショナル・ トゥース・クリーニングの有無, SRPを施行してか ら再評価までの期間が異なっており，それらの影響が 関与することも考えられる。そこで本研究は, 歯肉縁 上プラークコントロールの期間以外は同一の方法を用 い, SRP 後の歯周組織の改善にどのような違いがみ られるかについて臨床的検討を行った。

\section{材料および方法}

\section{1. 被験者および被験歯}

被験者は奥羽大学附属病院に来院し，成人型歯周炎 と診断された患者 36 名（男性 21 名, 女性 15 名, 平 均年歯 47.2 歳；28～71 歳）とした。それぞれの歯を 唇・煩側および口蓋・舌側の近心, 中央, 遠心の 6 歯 面に分け，初診時の診査でプロービングデプスが 2 $\mathrm{mm}$ 以下で，プロービング時の出血が認められない 健康な歯および部位を除外した 522 歯の 3,124 部位を 被験歯面とした。なお，保存不可能と診断あるいは治 療途中で抜去された歯は研究対象から除外した。被験 者の選択基準は全身疾患がないこと, 過去に歯周治療 を行った既往がないこととした。被験者はSRPまで 歯肉縁上プラークコントロールを行った期間から 1 , 2,3 および 6 力月 $(1 \mathrm{M}, 2 \mathrm{M}, 3 \mathrm{M}, 6 \mathrm{M})$ の 4 グ ループにランダムに分類した。各グループの詳細を表 1 に，ポケットごとの部位数を表 2 に示す。

\section{2. 処置内容}

初診時の診査に続き，歯周治療と口腔清掃指導に関 するモチベーションを行った後，プラークコントロー ル期間を設定した（1～6 カ月）。この期間中は通常の 歯ブラシに加えて，シングルタフテッドブラシ (TANDEX SOLO ${ }^{\circledR}$; HO 7, TANDEX A/S 社製, デンマーク）を用い，必要に応じて歯間ブラシ (APOTEK；DOFT AB 社製，スウェーデン）も併 用した。指導の間隔は $1 \sim 2$ 週間に 1 回とし, 指導後 には毎回プロフェッショナル・トゥース・クリーニン グを行った。その内容は, 低速エンジンにプロフィー ブラシおよびプロフィーカップ（\#0213，\#1800；サ ンデンタル株式会社，大阪）を装着し，ポリッシング クリーム（RDA 120 CCS PROPHY PASTE ; CCS, Clean Chenical Sweden AB 社製, スウェーデン) を介在させながら行った。隣接面でプラークを除去し きれない部位は, 補助的に歯間ブラシにポリッシング クリームをつけて清掃した。また，歯肉緑上歯石はこ の期間中に除去した。

プラークコントロール期間後の診査に続き，口腔内 をブロックごとに分け，ほぼ 1 週間隔でグレーシー型

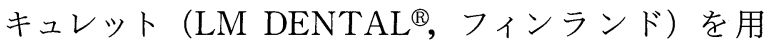
いて SRP を行った。SRP 終了後，1力月半は治癒期 間とした。この期間中は 2 週間に 1 度，口腔清掃の再 指導とプロフェッショナル・トゥース・クリーニング を繰り返した。その後, 歯周基本治療後の再評価を 
表 1 各グループにおける初診時の概要

\begin{tabular}{ccccc}
\hline 口腔清掃指導の期間 & $\begin{array}{c}\text { 患者数 } \\
\text { (男性, 女性) }\end{array}$ & 歯数 & $\begin{array}{c}\text { 被験歯面数 } \\
(\mathrm{n} \text { 数 }\end{array}$ & $\begin{array}{c}\text { 年歯 } \\
\text { (平均值 } \pm \text { S.D.) }\end{array}$ \\
\hline $1 \mathrm{M}$ & $9(5,4)$ & 141 & 842 & $45.0 \pm 10.7$ \\
$2 \mathrm{M}$ & $8(4,4)$ & 119 & 711 & $44.1 \pm 5.4$ \\
$3 \mathrm{M}$ & $8(4,4)$ & 121 & 722 & $49.3 \pm 8.6$ \\
$6 \mathrm{M}$ & $11(8,3)$ & 141 & 849 & $49.6 \pm 9.8$ \\
\hline
\end{tabular}

NS : Not significance (ANOVA)

表 2 初診時の PD ごとの部位数

\begin{tabular}{rcccccccccc}
\hline & $1 \mathrm{~mm}$ & $2 \mathrm{~mm}$ & $3 \mathrm{~mm}$ & $4 \mathrm{~mm}$ & $5 \mathrm{~mm}$ & $6 \mathrm{~mm}$ & $7 \mathrm{~mm}$ & $8 \mathrm{~mm}$ & $9 \mathrm{~mm}$ & 計 \\
\hline $1 \mathrm{M}$ & 0 & 98 & 158 & 177 & 207 & 96 & 60 & 30 & 16 & 842 \\
$2 \mathrm{M}$ & 0 & 40 & 132 & 171 & 212 & 93 & 37 & 15 & 11 & 711 \\
$3 \mathrm{M}$ & 3 & 67 & 158 & 191 & 192 & 70 & 19 & 19 & 3 & 722 \\
$4 \mathrm{M}$ & 3 & 61 & 132 & 190 & 225 & 109 & 75 & 33 & 21 & 849 \\
\hline
\end{tabular}

行った。

\section{3. 診査項目}

1) プラークコントロールレコード (PCR) : O' Leary らの方法 ${ }^{15)}$ を改良し, 隣接面は唇・煩側および 口蓋・舌側に分割して評価した。

2) プロービングデプス（PD）：歯肉辺縁からポ ケット底までの距離を $1 \mathrm{~mm}$ 間隔で測定した。

3）プロービングアタッチメントレベル (PAL) : セメントエナメル境またはクラウンのマージンからポ ケット底までの距離を $1 \mathrm{~mm}$ 間隔で測定した。

4) プロービング時の出血 (BOP) : プロービング 後, 30 秒以内に出血が認められたものを記録した。

それぞれの診査項目は 6 点法により記録し，各グ ループごとに初診時, SRP 前, 基本治療後の状態を 比較した。PD と BOPについては，初診時の PDの 深さを基準として，SRP 前と歯周基本治療終了後の 状態をそれぞれ比較した。PAL は歯周基本治療後の アタッチメントゲインまたはアタッチメントロスの割 合について評価した。

\section{4. 統計処理}

4 グループ間の比較には one-way ANOVA または Chi-square test を用いた。また，各グループ内での 診査時期の比較にはStudent $t$-test を用いた。また, 各臨床診査項目は初診時の状態において 4 グループ間 に有意差は認められなかった。

\section{結果}

\section{PCR の変化について}

各グループごとの PCR の変化を表 3 に示す。プ ラークコントロール期間の長短に関わらず，各グルー プとも SRP 前に平均 9.1〜 14.7\% と初診時から有意

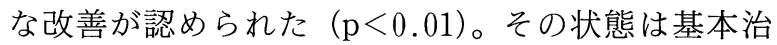
療後まで維持されていた。SRP 前, 基本治療後とも に 4 グループ間の差異は認められなかった。デー夕は 提示しないが, 初診時に PCR が高い被験者が基本治 療後にも高いという相関は認められなかった。

\section{PD の変化について}

各グループごとの PDの変化を表 4 に示す。各グ ループともに初診時, SRP 前, 基本治療後と有意な 減少（各 $\mathrm{p}<0.01 ）$ が認められた。

初診時の PDの深さごと分類した $\mathrm{SRP}$ 前の PDの 変化を図 1 に, 基本治療後の $\mathrm{PD}$ の変化を図 2 に示 す。SRP 前では, 初診時に $3 \sim 8 \mathrm{~mm}$ の部位において 4 グループ間で有意差が認められた（3～ $5 \mathrm{~mm}$ と 7 $\mathrm{mm}$ は $\mathrm{p}<0.05,6 \mathrm{~mm}$ と $8 \mathrm{~mm}$ は $\mathrm{p}<0.01)$ 。歯周治 療後では, 初診時に $3 \sim 5 \mathrm{~mm}$ の部位において 4 グ ループ間で有意差が認められた $(3 \mathrm{~mm}$ と $4 \mathrm{~mm}$ は $\mathrm{p}<0.01,5 \mathrm{~mm}$ は $\mathrm{p}<0.05) 。 2$ 群ずつを比較した場 合， $3 \mathrm{~mm}$ では 3 力月 $(2.3 \pm 1.1 \mathrm{~mm})$ および 6 力月 $(2.3 \pm 0.9 \mathrm{~mm})$ の グ ループが 1 カ月 $(2.7 \pm 1.1$ $\mathrm{mm})$ および 2 力月（2.6士0.8）のグループに対し有 意な減少を示した。 $4 \mathrm{~mm}$ では 3 カ月 $(2.7 \pm 1.4$ $\mathrm{mm})$ のグループが 1 カ月 $(3.2 \pm 1.1 \mathrm{~mm})$ および 2 
表 3 各グループにおける PCR の変化（平均値士S.D.）

\begin{tabular}{|c|c|c|}
\hline & $\mathrm{SRP}$ 前 & 基本治療後 \\
\hline $1 \mathrm{M}$ & $59.4 \pm 11.9 * * 9.1 \pm 5.8$ & $9.0 \pm 4.5$ \\
\hline $2 \mathrm{M}$ & $77.5 \pm 22.4 * * 11.6 \pm 5.1$ & $13.5 \pm 3.4$ \\
\hline $3 \mathrm{M}$ & $52.6 \pm 14.8 * * 14.7 \pm 4.7$ & $11.2 \pm 9.5$ \\
\hline \multirow[t]{2}{*}{$6 \mathrm{M}$} & $74.8 \pm 18.1 * * 13.2 \pm 12.0$ & $16.1 \pm 11.3$ \\
\hline & & $\begin{array}{c}\text { 単位 }(\%) \\
*: \mathrm{p}<0.01\end{array}$ \\
\hline
\end{tabular}

(Student $t$ test)
表 4 各グループにおける PD の変化（平均値 \pm S.D.）

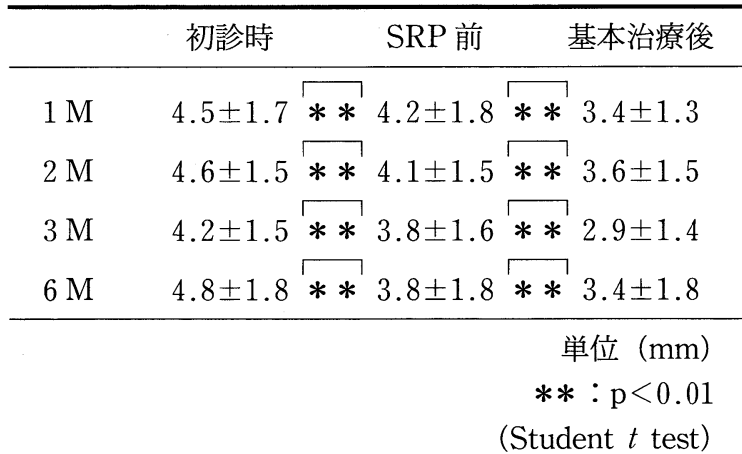

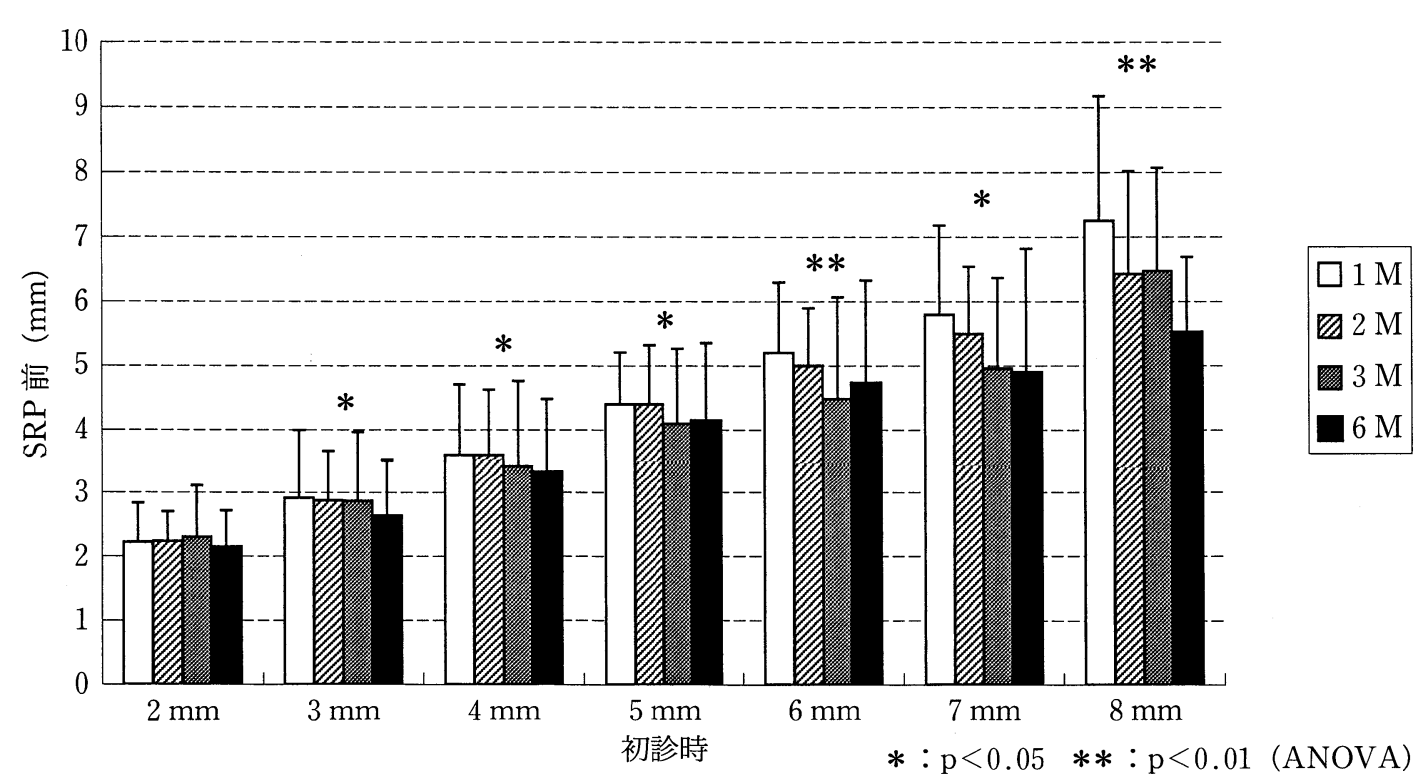

図 1 初診時の PD で分類した SRP 前の PD の変化 (平均值+S.D.)

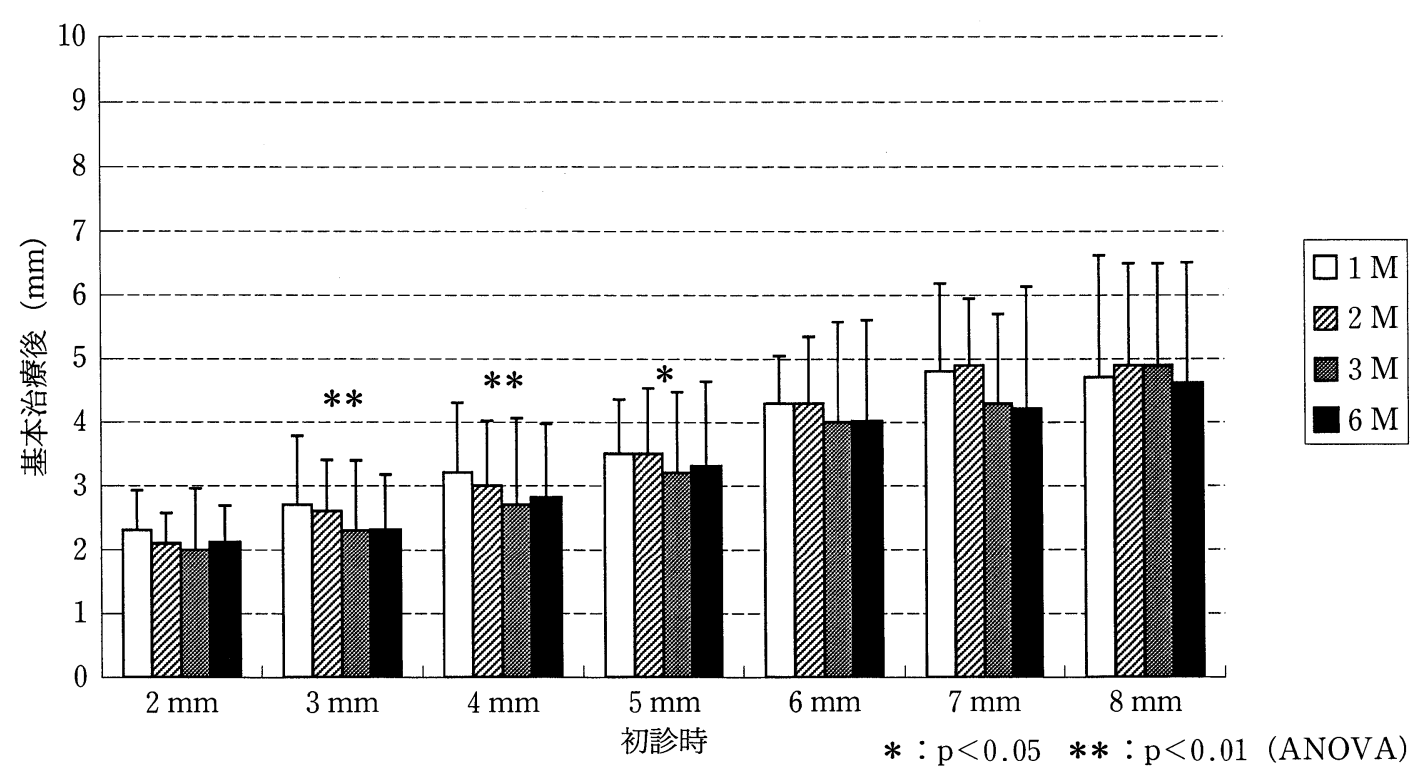

図 2 初診時の PD で分類した基本治療後の PD の変化（平均值+S.D.) 
表 5 各グループにおける PAL の変化(平均值 \pm S.D.)

\begin{tabular}{llllll}
\hline & 初診時 & SRP 前 & 基本治療後 \\
\hline $1 \mathrm{M}$ & $4.5 \pm 1.9$ & & $4.5 \pm 1.9$ * & $4.1 \pm 2.0$ \\
$2 \mathrm{M}$ & $4.6 \pm 1.9$ & $*$ & $4.4 \pm 2.0$ & $* *$ & $4.0 \pm 2.0$ \\
$3 \mathrm{M}$ & $4.7 \pm 1.7$ & $*$ & $4.5 \pm 1.8$ & $* *$ & $3.8 \pm 1.7$ \\
$6 \mathrm{M}$ & $5.0 \pm 1.9$ & $* *$ & $4.6 \pm 2.3$ & $4.5 \pm 2.0$ \\
\hline
\end{tabular}

単位 $(\mathrm{mm})$

$*: \mathrm{p}<0.05 * *: \mathrm{p}<0.01$

(Student $t$ test)

表 6 各グループにおける BOP の変化 (平均値 \pm S.D.)

\begin{tabular}{rrrr}
\hline & 初診時 & SRP 前 & 基本治療後 \\
\hline $1 \mathrm{M}$ & $65.0 \pm 22.6 * 40.1 \pm 11.7 * 21.6 \pm 14.3$ \\
$2 \mathrm{M}$ & $71.5 \pm 17.2 * 42.5 \pm 12.8 * 25.5 \pm 7.1$ \\
$3 \mathrm{M}$ & $87.5 \pm 12.9 * * 43.9 \pm 29.5 * 26.1 \pm 19.5$ \\
$6 \mathrm{M}$ & $84.5 \pm 14.0 * * 45.6 \pm 15.3 \quad 29.0 \pm 4.4$ \\
\hline & \multirow{3}{*}{$\begin{array}{r}\text { 単位 }(\%) \\
\text { (Student } t \text { test) }\end{array}$}
\end{tabular}

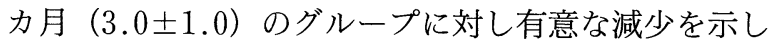
た。 $5 \mathrm{~mm}$ では 3 カ月 $(3.2 \pm 1.3 \mathrm{~mm})$ のグループが 1 カ月 $(3.5 \pm 0.9 \mathrm{~mm})$ および 2 力月 $(3.5 \pm 1.0)$ の グループに対し有意な減少を示した。

\section{PALの変化について}

各グループごとの PAL の変化を表 5 に示す。各グ ループともに有意なアタッチメントゲインが認められ たが，その時期は 1 カ月のグループでは SRP 前と基 本治療後の間 $(\mathrm{p}<0.05), 2$ 力月および 3 力月のグ ループでは初診時と SRP 前の間 $(\mathrm{p}<0.05)$, および $\mathrm{SRP}$ 前と基本治療後の間 $(\mathrm{p}<0.01), 6$ 力月のグ ループは初診時と SRP 前の間 $(\mathrm{p}<0.01)$ であった。

基本治療後のアタッチメントゲインまたはアタッチ メントロスの割合を図 3 に示す。各グループのゲイン ・不変・ロスの割合を比較すると, 3 力月および 6 力 月のグループと, 1 カ月および 2 力月のグループの間 にそれぞれ有意差が認められた $(\mathrm{p}<0.01)$ 。内訳と しては，アタッチメントロスの割合は 4 グループ間で ほほ同様であり，14.1〜 18.4\% の範囲であったが， 3 $\mathrm{mm}$ 以上のゲインが認められたものは 1 力月と 2 カ 月のグループがそれぞれ $4.4 \%$ であるのに対し, 3 力 月のグループでは $11.1 \%, 6$ カ月のグループでは $12.3 \%$ であった。また， 1〜 $2 \mathrm{~mm}$ のゲインは 1 カ月

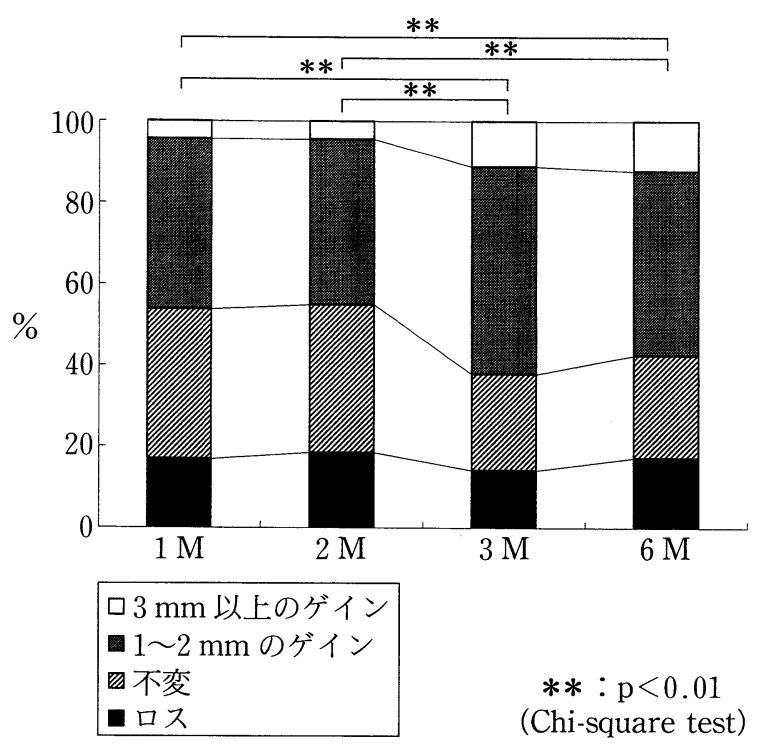

図 3 各グループにおける基本治療後の PAL の変化

で $41.8 \% ， 2$ 力月で $40.7 \% ， 3$ 力月で $51.0 \% ， 6$ 力月 で $45.2 \%$ であった。

\section{BOP の変化について}

各グループごとの BOP の変化を表 6 に示す。各グ ループともに有意な減少が認められたが，1 カ月と 2 カ月のグループは初診時, SRP 前, 基本治療後の間 でそれぞれ $\mathrm{p}<0.05,3$ カ月のグループでは初診時と $\mathrm{SRP}$ 前の間で $\mathrm{p}<0.01, \mathrm{SRP}$ 前と基本治療後の間で $\mathrm{p}<0.05,6$ カ月のグループでは初診時と SRP 前の間 で $\mathrm{p}<0.01$ であった。

初診時の PD で分類した基本治療後の BOP の割合 を図 4 に示す ( $\mathrm{N}$ 数は表 2 参照)。それぞれの深さに おける 4 グループ間の BOP の割合に有意差は認めら れなかった。デー夕は提示していないが，同様に分類 した SRP 前の BOP の割合も，4グループ間で有意 差は認められなかった。

\section{考察}

本研究はプロフェッショナル・トゥース・クリーニ ングと歯肉縁上スケーリングを含む歯肉縁上プラーク コントロール期間の違いが，SRP による歯肉縁下の 処置に対し，改善に影響を与えるかどうかについて臨 床的に検討した。すなわち，単にプラークコントロー ルの期間を延長することではなく，歯肉縁上の清掃状 態が管理され, 辺縁歯肉の炎症が改善する期間を設け ることで, 歯肉縁下への処置がより効果的であるかど うかを目的とした。

$\mathrm{PCR}$ は 1 カ月のグループでも SRP 前に平均 $9.1 \%$ 


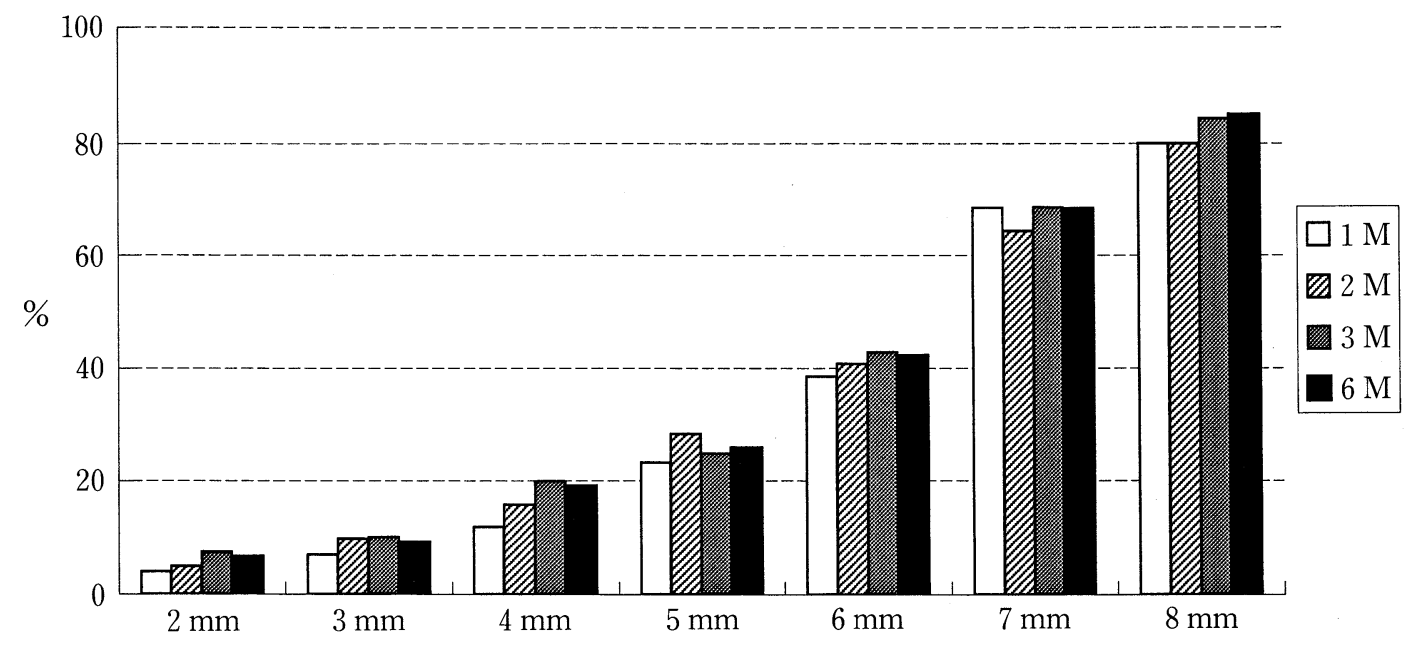

図 4 初診時の PD で分類した BOP の割合

であり, 他の研究 ${ }^{16,17)}$ と同様に, 早期の改善が認めら れた。また，PCRを $20 \%$ 以下に達成できた被験者の 割合は全グループで $88.6 \%$ であり，他の研究 ${ }^{16,18)}$ と 同様であった。しかしながら，本研究結果において各 グループごとの達成者の割合は 1 力月と 2 力月で $100 \%, 3$ 力月で $87.5 \%, 6$ 力月で $72.7 \%$ と，期間が 長くなるほど達成率が減少した。これは $20 \%$ 以下ま で達成できなかった被験者ばかりではなく, 一度達成 されたものの, 良好なプラークコントロールを維持で きなかったものも含まれている。すなわち，短期間に 集中して PCR を減少させることは簡単であるが, $\mathrm{SRP}$ や歯周外科などの治療を進めない状態で, 良好 なプラークコントロールを維持していくことは難しい という一面も表していると考えられる。

$\mathrm{PD}$ の平均減少量は 1 カ月では $1.1 \mathrm{~mm}$ であるのに 対し， 6 力月では $1.4 \mathrm{~mm}$ であった。これらは短期 $(1.09 \mathrm{~mm})^{13)}$ および長期 $(1.2 \mathrm{~mm})^{14)}$ の研究結果と ほぼ一致していた。初診時の PD で分類した減少は, $\mathrm{SRP}$ 前では 3〜 $8 \mathrm{~mm}$ において 4 グループ間に有意差 が認められた。SRP前はセルフ・コントロールとプ ロフェッショナル・トゥースクリーニングにより，歯 肉縁上の清掃状態が管理されていた。そのため, 辺縁 歯肉の炎症の消退によって歯肉退縮が起こり，ポケッ トが減少すると考えられる。相対的に歯肉縁下プラー クの一部は歯肉縁上に位置することになり，これが除 去されることによって, さらにポケットが浅くなると 考えられる。すなわち, 十分管理されたプラークコン トロール期間が長いほど，よりポケットが減少してい き，それが本研究結果に反映されたものと思われる。 一方, 基本治療後には 4 グループ間で有意差がみられ る範囲は3〜 $5 \mathrm{~mm}$ であった。ポケットの減少は歯肉
退縮に加えてアタッチメントゲインにもよる。ポケッ 卜底までスケーラーが十分到達する部位は, 歯肉退縮 とアタッチメントゲインによるポケットの減少が期待 できる。一方，ポケット底までスケーラーが到達せ ず，プラークや歯石の取り残しがみられる部位は，主 に歯肉退縮によってポケットが減少すると考えられ る。すなわち，プラークコントロール期間の違いによ り, SRP 前のポケットの減少に差ができ, それがそ のまま歯肉縁下プラークと歯石を十分除去できるかど うかの差となって現れたのが $3 \sim 5 \mathrm{~mm}$ の範囲であっ たと推察される。

PAL の変化は, アタッチメントゲインの割合は 3 カ月と 6 カ月のグループが, 1 カ月と 2 カ月のグルー プに比較して大きかった。これも PD に関しての考察 と同様に，SRP 時に歯肉縁下プラークを除去できる 深さに差があったためであると考えられる。すなわ ち，4グループ間で基本治療後の減少に差が認められ た PD は， 1 カ月と 2 カ月のグループに対し， 3 力月 または 6 カ月のグループであった。アタッチメントゲ イン・不変・ロスの割合でみられた有意差も, 1 力月 と 2 カ月のグループに対し, 3 カ月と 6 カ月のグルー プであったことから，3 カ月以上の管理されたプラー クコントロール期間を設定することは，歯肉退縮に よって歯肉縁下プラークと歯石を十分除去できる部位 を増し，それによって，アタッチメントゲインの割合 を増加させたものと考えられる。アタッチメントロス の割合は 4 グループ間でほほ同等であった。これは後 述する BOP（4グループ間で有意差なし）とも関連 するが，BOP は必ずしもアタッチメントロスの兆候 とはならないと報告19,20)されており，プラークコント ロール期間が長い（歯肉縁下の処置を行わない期間が 
長い）からといって，アタッチメントロスの割合が大 きくなるということは認められなかった。アタッチメ ントレベルに関しては, 初診時の PD とアタッチメン トゲイン/ロスの関係（歯肉縁上のコントロールだけ の方がアタッチメントロスを防げる深さ）について， 次報で詳細な検討を行う予定である。

BOP の割合は, 各グループの初診時から基本治療 後までの間に有意な改善がみられたものの，初診時の $\mathrm{PD}$ ごとに分類した場合, グループ間に有意差は認め られなかった。Glavind ら ${ }^{21)}$ は口腔清掃と歯肉出血の 関係について，6週，3 カ月および 6 力月で有意差は ないと報告しており，本研究結果で SRP 前のグルー プ間で差がみられなかったことと同様の結果であっ た。これは歯肉退縮によってポケットが浅くなったと しても，歯肉縁下プラークは残存しているためである と考えられる。SRP後にもグループ間で BOP に有 意差が認められない理由としては, 深いポケット，根 分岐部病変 ${ }^{22)}$, 楔状骨欠損, 根面の縦溝など, 歯肉縁 下プラークと歯石を取り残す因子が存在したためと考 えられる。おそらく，このような因子が存在する部位 と BOP の残存率の間には関連があるものと考えられ るので，今後詳細な検討を行う予定である。

本研究結果では BOP の改善はプラークコントロー ルの設定期間の違いで差は認められなかったが, PD と PAL は 3 カ月以上の期間を設定することで, 有意 な改善を認めた。また, 改善の程度に差があった初診 時の PD は 3〜 $5 \mathrm{~mm}$ であった。基本治療後に治癒が 認められない部位は, 歯周外科か再 SRP が選択され る。初診時の PD が 3〜 $5 \mathrm{~mm}$ の範囲で基本治療後に $\mathrm{BOP}$ が残存している部位は, 再 SRP が適用される ものと考えられる。しかし, 繰り返しの SRP と治癒

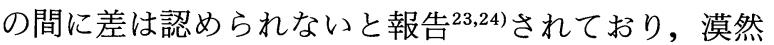
と SRP を繰り返し, 露出象牙質を多くすることは歯 周疾患の再発の危険性 ${ }^{25,26)}$ が考慮される。そこで，再 生能が低いセメント質を可及的に保存すること年を目 標にするならば，3 カ月以上の管理された歯肉縁上プ ラークコントロール期間を設定することは, 非外科処 置症例において有効であると考えられる。

\section{文献}

1) Nyman, S., Rosling, B. and Lindhc, J. : Effect of professional tooth cleaning on healing after periodontal surgery. J. Clin. Periodontol., $2: 80-86$, 1975.

2) Axelsson, P. and Lindhe, J. : The significance of maintenance care in the treatment of periodontal disease. J. Clin. Periodontol., 8 : 281-294, 1981.

3) Tabita, P.V., Bissada, N.F. and Maybury, J.E. : Effectiveness of supragingival plaque control on the development of subgingival plaque and gingival inflammation in patients with moderate pocket depth. J. Periodontol., 52:88-93, 1981.

4) Siegrist, B. and Kornman, K.S. : The effect of supragingival plaque control on the composition of the subgingival microbial flora in ligatureinduced periodontitis in the monkey. J. Dent. Res., $61:$ 936-941, 1982.

5) Kho, P., Smales, F.C. and Hardie, J.M. : The effect of supragingival plaque control on the subgingival microflora. J. Clin. Periodontol., $12: 676$ -686, 1985.

6) Beltrami, M., Bickel, M. and Baehni, P.C. : The effect of supragingival plaque control on the composition of the subgingival microflora in human periodontitis. J. Clin. Periodontol., 14: 161-164, 1987.

7) Dahlen, G., Lindhe, J., Sato, K., Hanamura, H., and Okamoto, H.: The effect of supragingival plaque control on the subgingival microbiota in subjects with periodontal disease. J. Clin. Periodontol., 19 : 802-809, 1992.

8) Badersten, A., Nilveus, R. and Egelberg, J. : Effect of nonsurgical periodontal therapy. II. Severely advanced periodontitis. J. Clin. Periodontol., $11: 63-76,1984$.

9) Loos, B., Claffey, N. and Crigger, M. : Effects of oral hygiene measures on clinical and microbiological parameters of periodontal disease. J. Clin. Periodontol., $15: 211-216,1988$.

10) Sato, K., Yoneyama, T., Okamoto, H., Dahlen, G. and Lindhe, J. : The effect of subgingival debridement on periodontal disease parameters and the subgingival microbiota. J. Clin. Periodontol., 20 : 359-365, 1993.

11) Westfelt, E., Rylander, H., Dahlen, G. and Lindhe, J. : The effect of supragingival plaque control on the progression of advanced periodontal disease. J. Clin. Periodontol., 25 : 536-541, 1998.

12) Morrison, E.C., Ramfjord, S.P. and Hill, R.W. : Short-term effects of initial, nonsurgical periodontal treatment (hygienic phase). J. Clin. Periodontol., $7:$ 199-211, 1980.

13) Hammmerle, C.H., Juss, A. anld Lang, N.P. : Shur lterm effects of initial periodontal therapy (hygienic phase). J. Clin. Periodontol., 18:233-239, 1991.

14) Cercek, J.F., Kiger, R.D., Garrett, S. and Egelberg, J. : Relative effects of plaque control and instru- 
mentation on the clinical parameters of human periodontal disease. J. Clin. Periodontol., $10: 46^{-}$ 56, 1983.

15) O'Leary, T.J., Drake, R.B. and Naylor, J.E. : The plaque control record. J. Periodontol., $43: 38$, 1972.

16）李 文昭，塩野宗則，鈴木丈一郎，武山和夫，片井 秀典, 野村典生, 新井 高, 中村治郎：歯周初期治 療における O'Leary らの Plaque control record の 推移. 日歯周誌, $28: 252-262,1986$.

17）松永 信，瀬戸口尚志，中村睦美，横田 誠，末田 武：初期治療におけるポケットの減少とプラークコ ントロールとの関係について. 日歯周誌, 31：717$723,1989$.

18）武田康篤, 堀井 昇, 光崎潤子, 田中裕子, 安藤芳 明，鈴木基之，宮下 元：歯周病患者に扔ける口腔 清掃後のプラークスコアの改善について．日歯周 誌, $32 ： 289-298,1989$.

19) Kaldahl, W.B., Kalkwarf, K.L., Patil, K.D. and Molvar, M.P. : Relationship of gingival bleeding, gingival suppuration, and supragingival plaque to attachment loss. J. Periodontol., 61:347-351, 1990.

20) Claffey, N. and Egelberg, J. : Clinical characteristics of periodontal sites with probing attachment loss following initial periodontal treatment. J. Clin. Periodontol., 21 : 670-679, 1994.

21) Glavind, L., Zeuner, E. and Attstrom, R. : Oral hygiene instruction of adults by means of a selfinstruction manual. J. Clin. Periodontol., $8: 165^{-}$ 176, 1981.

22) Nordland, P., Garrett, S., Kiger, R., Vanooteghem, R., Hutchens, L.H. and Egelberg, J. : The effect of plaque control and root debridement in molar teeth. J. Clin. Periodontol., 14 : 231-236, 1987.

23) Badersten, A., Nilveus, R. and Egelberg, J. : Effect of nonsurgical periodontal therapy. III. Single versus repeated instrumentation. J. Clin. Periodontol., 11 : 114-124, 1984.

24) Anderson, G.B., Palmer, J.A., Bye, F.L., Smith, B. A. and Caffesse, R.G. : Effectiveness of subgingival scaling and root planing: single versus multiple episodes of instrumentation. J. Periodontol., $67: 367-373,1996$.

25) Adriaens, P.A., De Boever, J.A. and Loesche, W. J. : Bacterial invasion in root cementum and radicular dentin of periodontally diseased teeth in humans. J. Periodontol., 59 : 222-230, 1988.

26) Adriaens, P.A., Edwards, C.A., De Boever, J.A. and Loesche, W.J. : Ultrastructural observation on bacterial invasion in cementum and radicular dentin of periodontally diseased human teeth. J. Periodontol., 59：493-503, 1988.

27）鈴木史彦：歯周病罹患歯根面に対するルートプレー ニングの細菌学的評価. 奥羽大歯学誌, $22: 54-66$, 1995.

\section{連絡先：}

奥羽大学歯学部歯科保存学第一講座

干 963-8611 福島県郡山市富田町字三角堂 31-1 